\title{
Ameliorative role of Arabic gum against nephrotoxicity induced by ciprofloxacin in rats
}

\author{
A.D. Abdullah $\mathbb{D}^{\circ}$ and M.A. Ahmed \\ Department of Biology, College of Education for Pure Science, Tikrit University, Tikrit, Iraq
}

\begin{tabular}{l} 
Article information \\
\hline Article history: \\
Received June 24, 2020 \\
Accepted August 30, 2020 \\
Available online October 1, 2021 \\
\hline Keywords: \\
Arabic gum \\
Ciprofloxacin \\
Nephrotoxicity \\
Antioxidants \\
MDA \\
\hline
\end{tabular}

Correspondence:

M.A. Ahmed

dr.measerahmed@tu.edu.iq

\begin{abstract}
Medicinal plants have gained wide popularity at present time due the side effects of chemical drugs on the body in general and on the kidneys in particular. This study aimed to explore the protective effect of Arabic gum (AG) against nephrotoxicity of ciprofloxacin. Twenty-four rats divided into four groups administrated for 14 days as following: control group administrated orally with distilled water $1 \mathrm{ml} / \mathrm{kg}$, ciprofloxacin group $750 \mathrm{mg} / \mathrm{kg}$, orally. Third group administrated with AG solution $15 \%$ and fourth group administrated with ciprofloxacin $750 \mathrm{mg} / \mathrm{kg}$ combined with AG $15 \%$ respectively. Results demonstrated the effect of Ciprofloxacin in significant increased levels of nephrotoxicity biomarkers such as blood urea nitrogen, creatinine, uric acid, MDA, and a significant decreased urine flow rate, creatinine clearance and degeneration in renal tissue via attenuate antioxidant system tissue. The combined administration of AG with Ciprofloxacin showed the ameliorative role of AG on nephrotoxicity biomarkers, nephron function, antioxidant availability and protected renal tissue from damage. We concluded that AG in concentration $15 \%$ has a protective role against renal toxicity exposed by ciprofloxacin in rats.
\end{abstract}

DOI: 10.33899/ijvs.2020.127441.1503, (CAuthors, 2021, College of Veterinary Medicine, University of Mosul.

This is an open access article under the CC BY 4.0 license (http://creativecommons.org/licenses/by/4.0/).

\section{Introduction}

Nephrotoxicity is when renal nephron`s ability to detoxification and excretion obstructed by toxicant (1). The kidney is the most important control system that maintains the body homeostasis and drains endogenous or exogenous toxicants (2).

Exposure to some chemical drugs often induced nephron's toxicity, and damage tissues. Around $20 \%$ of nephrotoxicity cases cause by drugs and the percentage raised approximately to $66 \%$ in elderly who exposure to drugs (3).

The pathogenic effect of most chemical drugs lead to nephrotoxicity include tubular toxicity, crystals formation, inflammations, altered in glomerular hemodynamic (4).

Ciprofloxacin approved by Food and Drug agency FDA in 1987 , it is the $2^{\text {nd }}$ generation of fluoroquinolone family produces antibiotics against several bacterial infections via inhibiting DNA gyrase and topoisomerase IV in bacteria preventing bacterial replication (5).

Arabic Gum (AG) defined by FAO and WHO as a dried exudation obtained from the stems of Acacia plant belongs to the Leguminosae family; Chemically Arabic Gum is a complex polysaccharide branched-chain, slightly acidic, mixed with calcium, potassium, and magnesium.

The backbone units contain $\beta$-D- galactopyranosyl units joined to side chains of $\beta$-L- rhamnopyranose, $\beta \mathrm{D}$ glucuronic acid, $\alpha \mathrm{L}$ arabinofuranosyl, and $\beta \mathrm{D}$ galactopyroanose by 1,6- linkages (6). Arabic gum dissolves easily in water and gives color varies from pale yellow to orange - brown. Pharmacologically Arabic gum experimentally used as an antioxidant treatment against hepatic and renal toxicities (7).

The Study aimed to identify the protective and ameliorative role of Arabic gum solution against nephrotoxicity induced by oxidative damage. 


\section{Materials and methods}

\section{Collection and preparation of Arabic gum}

The Arabic gum obtained from Sudan in August 2019 the gum was washed and dried at room temperature $25 \pm 2{ }^{\circ} \mathrm{C}$, then crushed and melt in water in concentration $15 \%$ according to active dose experiment (8).

\section{Preparation of experimental subjects}

Twenty-four healthy male rats weighed 190-220 g, and aged 6-7 weeks housed in an animal unit, College of Vet. Med. Medicine, University of Tikrit. Rats underwent to standard laboratory conditions (9), and free to access to food and water during the experimental period of 14 days. Rats distributed into four groups: Control group administrated with distilled water $1 \mathrm{ml} / \mathrm{kg}$ orally using tubular gavage, second group administrated with Ciprofloxacin $750 \mathrm{mg} / \mathrm{kg}$ orally, and third group administrated with a solution of Arabic gum solution $15 \%$ orally and fourth group administrated with both Ciprofloxacin $750 \mathrm{mg} / \mathrm{kg}$ and Arabic gum solution $15 \%$. The administrated doses settled according to pretest to determine the active dose (8).

\section{Urine sample collection}

At the end of the experiment period rats caged individually in metabolic cages designed to collect and measure urine volume within 24 hours.

\section{Blood sample preparation}

Rats anesthetized by ether and blood was taken from jugular vein. blood centrifuged at $3000 \mathrm{rpm}$ for 15 minutes to obtain the serum. Serum kept in a deep freeze $-80^{\circ} \mathrm{C}$ until biochemical tests performed $(9,10)$.

\section{Kidney tissue homogenization}

Kidney removed immediately, $1 \mathrm{~g}$ of tissue weighted, harvested, and placed in $10 \mathrm{ml}$ of cold homogenization medium at $4^{\circ} \mathrm{C}$ composed of $0.25 \mathrm{M}$ sucrose, $20 \mathrm{mM}$ Tris$\mathrm{HCl}$ buffer $\mathrm{pH} 7.4$ and $1 \mathrm{mM}$ EDTA. The tissue homogenized by electrical homogenizer $16000 \mathrm{rpm}$ for 30 seconds then centrifuged at $3000 \mathrm{rpm}$ for 15 minutes. The supernatant used for biochemistry tests (11).

\section{Histological study}

Kidney tissue obtained immediately fixed in $10 \%$ formalin for 24 hours then washed by water then dehydrated using the series concentration of alcohol, samples cleared and infiltrated then embedded in paraffin, and sectioned to $5 \mu \mathrm{m}$ thickness by an electric rotary microtome. Sections stained by hematoxylin and eosin, and examined under a light of optical microscope (12).

\section{Nephrotoxicity diagnosis}

In this study, nephrotoxicity determined by measuring concentrations of creatinine, blood urea nitrogen (BUN), creatinine clearance, uric acid, $\mathrm{Na} / \mathrm{K}$ in serum. Glutathione
(GSH), superoxide dismutase (SOD), and malondialdehyde (MDA) measured in serum and homogenized tissue (13).

\section{Measurement of blood urea nitrogen}

The concentration of blood urea nitrogen measured by a chemical method provide with an analyzing kit (Agappe, Switzerland). The basic principle is urea hydrolyzed by urease to give a complex of ammonia and carbon dioxide. The absorbance of the reaction measured spectrophotometry at wavelength $590 \mathrm{~nm}(13,14)$.

\section{Measurement of creatinine}

Creatinine measured spectrophotometry using an analyzing kit (Biomaghreb Company, Tunis). The basic principle depends on the interaction of creatinine present in the blood serum with alkaline picrate to produce a complex of creatinine picrate and has the highest absorbance at wavelength $490 \mathrm{~nm}(13,15)$

\section{Measurement of creatinine clearance}

The method depends on the calculating equation $\mathrm{Cr} . \mathrm{cl}=$ urine creatinine $(\mathrm{mg} / \mathrm{dl}) \quad \mathrm{x}$ urine flow $(\mathrm{mL} / \mathrm{min})$ /Serum creatinine (mg/dl) (13).

\section{Measurement of uric acid}

The method applied according to the kit Procedure provided by (BIOLABO, France). The basic principle depends on uricase to act on uric acid to produce allantoin, carbon dioxide, and hydrogen peroxide, then reacts with a chromogen to form a complex gives a red color can be absorbed at $520 \mathrm{~nm}(13,15)$.

\section{Measurements of oxidant - antioxidant}

Lipid peroxidation determined via MDA which make a complex with Thiobarbituric acid (TBA) gives pink color can be absorbed spectrophotometry at $532 \mathrm{~nm} \mathrm{(16).}$ Glutathione level proceed based on the Ellamn reagent method, the sulfhydryl group interact German reagent in an alkaline medium to form sulfured compound and TNB the complex gives a yellow color absorbed via spectrophotometer at $412 \mathrm{~nm} \mathrm{(17).} \mathrm{The} \mathrm{superoxide}$ dismutase SOD activity evaluated based on the degradation of the nitro blue tetrazolium by the superoxide radical. Resulted color absorbed in spectrophotometer at $560 \mathrm{~nm}$ (17).

\section{Statistical analysis}

The experimental data analyzed via One Way ANOVA independent sample tests and the differences among groups achieved using Duncan multiple range test (18).

\section{Results}

Administration of Ciprofloxacin significantly increased levels of urea, creatinine, uric acid, $\mathrm{Na}^{+}$, and GSH, MDA and extracted tissue and a significantly decreased creatinine in 
the urine, creatinine clearance, and GSH in serum in comparison to control group. Administration of AG significantly increased levels of creatinine clearance, $\mathrm{K}^{+}$, and MDA, but there was a significant decrease in the levels of uric acid, and urine creatinine, $\mathrm{Na}^{+}$, and GSH. While no significant differences appeared in the level of urea, creatinine, and GSH, SOD, and MDA compared to the control group. The combined administration of ciprofloxacin and AG showed the ability of AG in decreasing levels of uric acid, urea, creatinine, creatinine clearance, $\mathrm{Na}+$ and MDA in kidney tissue while there were elevating in levels of $\mathrm{K}+$, $\mathrm{GSH}$, in serum, SOD in homogenized tissue, and MDA in serum (Tables 1 and 2) (Figures 1-4).

Table 1: Effect of Ciprofloxacin and Arabic gum on nephrotoxicity indicators

\begin{tabular}{lcccc}
\hline & \multicolumn{4}{c}{ mean \pm SE $(\mathrm{n}=6)$} \\
\cline { 2 - 5 } & Control & Ciprofloxacin & Arabic Gum & Ciprofloxacin + Arabic Gum \\
\hline Uric acid $(\mathrm{mg} / \mathrm{dl})$ & $1.376 \pm 0.097$ & $1.561 \pm 0.157^{*}$ & $1.026 \pm 0.051^{* * *}$ & $1.330 \pm 0.014^{*}$ \\
Blood urea nitrogen $(\mathrm{mg} / \mathrm{dl})$ & $25.846 \pm 3.27$ & $40.697 \pm 3.395^{* *}$ & $28.962 \pm 2.614^{\mathrm{N} . S}$ & $34.416 \pm 2.084^{*}$ \\
Creatinine $(\mathrm{mg} / \mathrm{dl})$ & $0.468 \pm 0.040$ & $0.691 \pm 0.043^{*}$ & $0.547 \pm 0.006^{*}$ & $0.567 \pm 0.029^{*}$ \\
Urine creatinine $(\mathrm{mg} / \mathrm{dl})$ & $25.52 \pm 0.141$ & $19.193 \pm 0.099^{* *}$ & $23.892 \pm 0.115^{\mathrm{N} . \mathrm{S}}$ & $14.353 \pm 0.141^{* *}$ \\
\hline
\end{tabular}

$*=$ significant at $\mathrm{P}<0.05$. **= significant at $\mathrm{P}<0.01$.

Table 2: Effect of ciprofloxacin and Arabic gum on antioxidants concentration in serum and kidney homogenized tissue

\begin{tabular}{lcccc}
\hline & \multicolumn{4}{c}{ mean \pm SE $(\mathrm{n}=6)$} \\
\cline { 2 - 5 } & Control & Ciprofloxacin & Arabic Gum & Ciprofloxacin + Arabic Gum \\
\hline GSH $(\mu \mathrm{mol} / \mathrm{l})$ & $32.267 \pm 2.123$ & $28.063 \pm 2.472^{*}$ & $33.463 \pm 4.367^{\text {N.S }}$ & $32.842 \pm 1.704^{*}$ \\
SOD $(\mu \mathrm{mol} / \mathrm{l})$ & $13.071 \pm 0.229$ & $13.359 \pm 0.076^{\text {N.S }}$ & $12.259 \pm 0.720^{\text {N.S }}$ & $13.018 \pm 0.072^{\text {N.S }}$ \\
MDA $(\mu \mathrm{mol} / \mathrm{l})$ & $0.882 \pm 0.031$ & $1.560 \pm 0.043^{*}$ & $4.337 \pm 0.047^{* *}$ & $3.485 \pm 0.052^{*}$ \\
GSH-k $(\mu \mathrm{mol} / \mathrm{g})$ & $69.803 \pm 8.694$ & $77.982 \pm 6.545^{*}$ & $55.799 \pm 0.591^{* *}$ & $84.921 \pm 1.442^{* *}$ \\
SOD-k $(\mu \mathrm{mol} / \mathrm{g})$ & $9.407 \pm 0.749$ & $8.086 \pm 0.836^{*}$ & $10.059 \pm 0.462^{*}$ & $11.381 \pm 0.251^{* * *}$ \\
MDA- $\mathrm{k}(\mu \mathrm{mol} / \mathrm{g})$ & $5.190 \pm 0.76$ & $7.702 \pm 0.410^{* *}$ & $5.223 \pm 0.216^{\text {N.S }}$ & $4.322 \pm 0.328^{* *}$ \\
\hline
\end{tabular}

*= significant at $\mathrm{P}<0.05$. **= significant at $\mathrm{P}<0.01$.

\section{Discussion}

Ciprofloxacin nephrotoxicity is associated with renal damage. Ciprofloxacin caused atrophy in the glomerulus and renal cell toxicity leads to necrosis and degeneration in renal tubular cells. Which obstruct tubular function, activate inflammatory cascades, elevating lipid peroxidation and increase ROS influence body to use antioxidant systems such as GSH and SOD to avoid oxidative stress. ROS can activate TNF- $\alpha$ that stimulates apoptosis and necrosis in tubular cells due to inhibit Anti-apoptosis enzymes (19).

Tubular injury increases reabsorption of uric acid and raise its levels in serum. High uric acid combined with drugs is the most causes of nephropathy and induced acute kidney injury (20).

Fluoroquinolone has been involved in rhabdomyolysis and musculoskeletal complication due multifactorial activation of ROS, alteration in cell signaling, and the atom of fluorine cause myotoxicity, then increases concentration of creatinine. Also high levels of ROS inhibit insulin secretion influence the cell to utilize proteins and fats oxidation to provide energy, which increase urea and creatinine levels (21).

Quinolones appeared to increase the synthesis of the antidiuretic hormone $\mathrm{ADH}$, so the urine flow rate and creatinine clearance decreased, the mechanism is not fully understood, but it is proposed that quinolones can cross blood-brain barrier and stimulate synthesis and release of ADH (22). Also restricted sodium in serum increases reabsorption of water, urea, and decreases urine flow rate. Ciprofloxacin has low solubility in urine resulting in crystallization precipitate within distal tubules obstructing urine flow and increase inflammation (23). Arabic Gum has chemical compounds that have antioxidant properties such as phenols, flavonoids, amino acids and zinc (7). These antioxidant compounds ameliorated the antioxidant capacity in renal injured tissue and attenuated lipid peroxidation in subjects exposed to damages via Ciprofloxacin. AG rehabilitated glomerular shape, and has a protective function against nephrotoxicity observed through reduction of BUN, Creatinine, uric acid, and sodium levels and enhance urine flow rate, creatinine clearance, and potassium levels. The reduction in creatinine levels in serum refers to the protective role of AG against myotoxicity and enhance renal function. According to laboratory experiments AG administration elevating creatinine clearance, increases urinary flow rate, inhibit ADH and increases excretion of phosphate and $\mathrm{Na}+$. Studies of showed that AG has antioxidant and antiinflammatory properties preventing free radical's generation and inflammation associated with apoptosis and necrosis (24). AG contains zinc, which increases production of GSH, and SOD in tissue exposed to oxidative stress and decrease 
levels of MDA, and keeps normality of tissue due zinc protein fingers role in DNA repairing and regulation of apoptosis (25) and that observed in this study. GSH and SOD were in a significant level in homogenized tissue more than serum, which refers to the earlier response to increase production of GSH, and SOD influenced by AG.

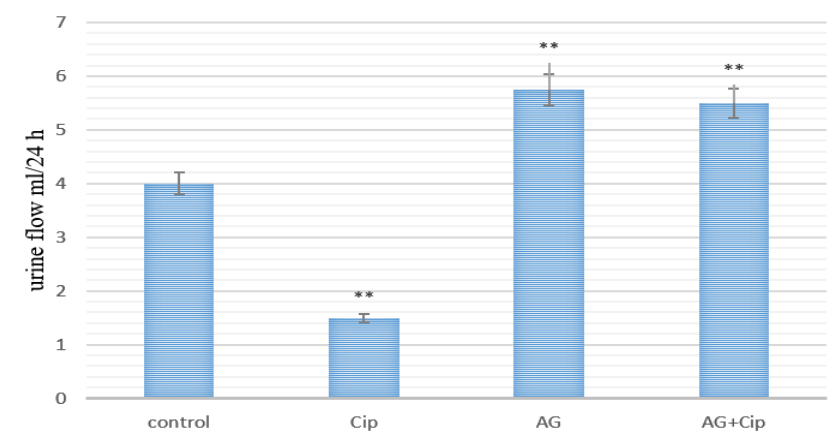

Figure 1: Effect of Ciprofloxacin and Arabic gum on level of urine flow rate. Cipro. = Ciprofloxacin $750 \mathrm{mg} / \mathrm{kg}$. AG= Arabic Gum $15 \%$ of solution. * $=$ significant at $\mathrm{P}<0.05$. **= significant at $\mathrm{P}<0.01$.

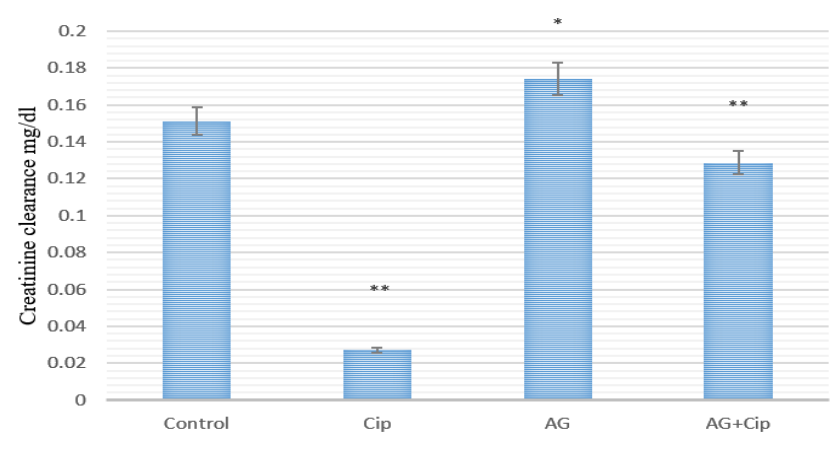

Figure 2: Effect of Ciprofloxacin and Arabic gum on level of creatinine clearance. Cipro. = Ciprofloxacin $750 \mathrm{mg} / \mathrm{kg}$. $\mathrm{AG}=$ Arabic Gum $15 \%$ of solution. *= significant at $\mathrm{P}<0.05$. $* *=$ significant at $\mathrm{P}<0.01$.

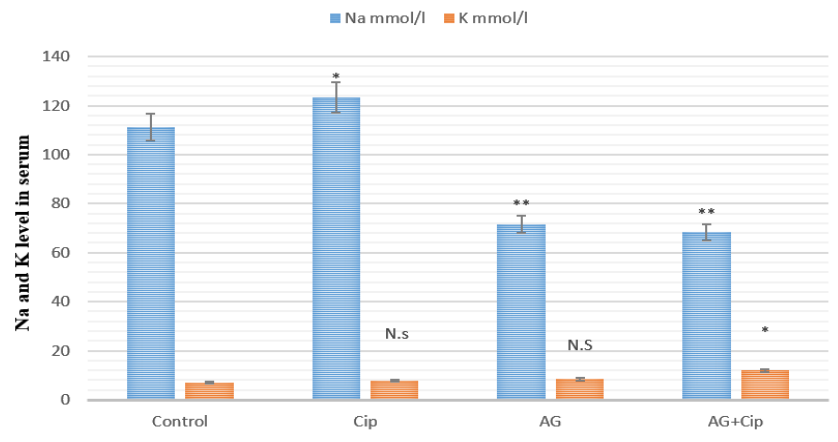

Figure 3: effect of Ciprofloxacin and Arabic gum on $\mathrm{Na}+$ and $\mathrm{K}+$ levels in serum. Cipro. $=$ Ciprofloxacin $750 \mathrm{mg} / \mathrm{kg}$. AG= Arabic Gum $15 \%$ of solution. * = significant at $\mathrm{P}<0.05$. **= significant at $\mathrm{P}<0.01$.

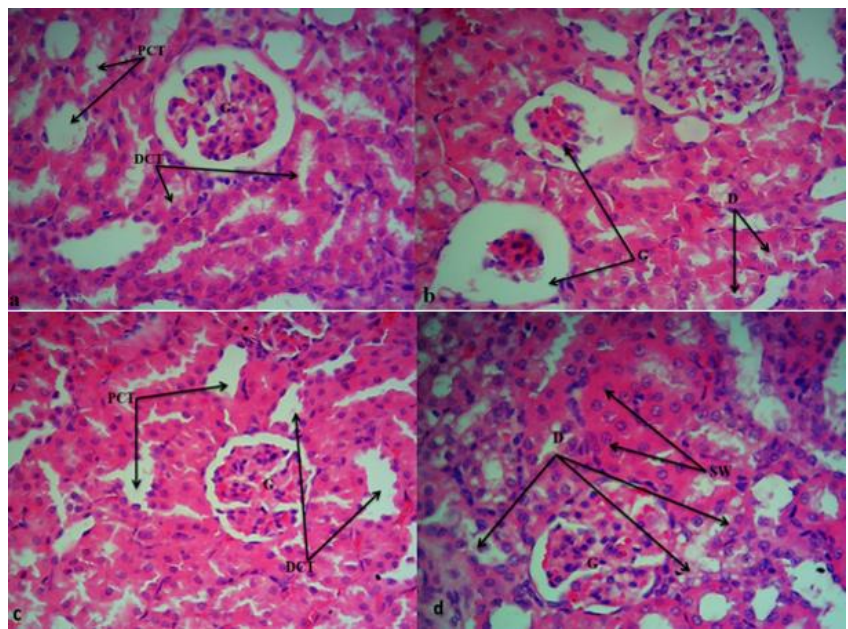

Figure 4: a: Control group showing normal kidney tissue glomeruli (G), proximal (PCT) and distal tubular (DCT). b: Damage in kidney tissue resulted via Ciprofloxacin, degeneration in renal tubular (D), glomerular atrophy (G). c: normal kidney tissue after Arabic gum administration. d: swelling (SW) and degeneration (D) in some tubular with normal glomerular (G) after administration with Arabic gum and Ciprofloxacin. (H\&E, 40x).

\section{Conclusion}

We concluded that AG in concentration $15 \%$ has a protective role against renal toxicity exposed by ciprofloxacin in rats.

\section{Acknowledgments.}

The authors appreciate and thanks, the staff of animal facility unit in Veterinary Medicine College, university of Tikrit for their help in complete this scientific study.

\section{Conflict of interest}

No conflict.

\section{References}

1. Ferguson MA, Vaidya VS, Bonventre JV. Biomarkers of nephrotoxic acute kidney injury. Toxicol. 2008;245:182-193 DOI: 10.10.1016/j.tox.2007.12.024

2. Kohli HS, Bhaskaran MC, Muthukumar T, Thennarasu K, Sud K, Jha V, Gupta KL, Sakhuja V. Treatment-related acute renal failure in the elderly: A hospital-based prospective study. Nephrol Dial Transplant. 2000;15:212-217.DOI: $10.093 / \mathrm{ndt} / 15.2 .212$

3. Nagai J, Takano M. Molecular-targeted approaches to reduce renal accumulation of nephrotoxic drugs. Expert Opin Drug Metab Toxicol. 2010;6:1125-1138. DOI: 10.10.1517/17425255.2010.497140

4. Kim S, Moon A. Drug induced nephrotoxicity and its biomarkers. Biomol Ther. 2012;20(3):268-272. DOI: 10.10.4062molther.20.3.268

5. Meyerhoff A, Albrecht R, Meyer J, Dionne P, Higgins K, Murphy D. US food and drug administration approval of ciprofloxacin hydrochloride for management of postexposure inhalational anthrax. Clin Infections Dis. 2004;39(3):303-308. DOI: $\underline{10.10 .1086 / 421491}$ 
6. Ali BH, Ziada A, Blunden G. Biological effects of gum arabic: A review of some recent research. Food Chem Toxicol. 2009;47(8):1-8. DOI: $10.10 .1016 /$ j.fct.2008.07.001

7. Lopez TL, Nigen M, Williams P, Doco T, Sanchez C. Acacia senegal vs. Acacia seyal gums-part 1: Composition and structure of hyperbranched plant exudates. Food Hydrocol. 2015;51:41-53. DOI: 10.10.1016.j.foodhyd.2015.04.019

8. Al-Musawi HT, Al-Tai MI, Al-Musawi MT. The effect of the phenolic and other active compounds of the alcohol and acid extracts of cinnamon on some of the biochemical parameters of induced diabetes mellitus. J Biotech Res Cent. 2015;9(1):24-36. [available at]

9. Mustafa KA, Al-Baggou BK. Toxicological and neurobehavioral effects of chlorpyrifos and deltamethrin insecticides in mice. Iraqi J Vet Sci. 2020;34(1):189-196. DOI: 10.10.33899/ijvs.2019.125738.1144

10. Ahmed MA. Protective effect of aqueous extract of Alhagi maurorum in spermatogenesis and antioxidant status of adult rats exposed to carbon tetrachloride. Iraqi J Vet Sci. 2019 ;33(1):1-7. DOI: 10.10.33899/ijvs.2019.125509.1031

11. Graham JM. Homogenization of mammalian tissues. Sci World J. 2002;2:1626-1629. DOI: $10.1100 /$ tsw.2002.849

12. Al-Haaik AG. A gross anatomical and histological study of pancreas in adult Kestrel (Falco tinnunculus). Iraqi J Vet Sci. 2019;33(2):175-180. DOI: $10.10 .33899 /$ ijvs.2019.162960

13. Wu A, Tietz NW. Clinical guide to laboratory test. $4^{\text {th }}$ ed. New York: CRP; 2006. 1096-1099 p.

14. Jasim RF, Allwsh TA. Effect of plasma isolated Orexin-A on the regulation of metabolites in male rats. Iraqi J Vet Sci,2021;35(3):451457.DOI: $10.10 .33899 /$ ijvs.2020.127001.1429

15. Boumezrag A, Hemida H, Boumezrag FA, Smail F, Cisse S. Pathological and biological effects of treatments with lambdacyhalothrin in rabbits. Iraqi J Vet Sci. 2021;35(3):443-450. DOI: 10.10.33899/ijvs.2020.126977.1425

16. Al-Abdaly YZ, Saeed MG, Al-Hashemi HM. Effect of methotrexate and aspirin interaction and its relationship to oxidative stress in rats. Iraqi J Vet Sci. 2021;35(1):151-156. DOI: 10.10.33899/ijvs.2020..1335

17. Ellman GL. Tissue sulfhydryl groups. Arch Biochem Biophys. 1959;82:70-77. DOI: 10.10.1016/0003-9861(59)90090-6

18. Gentle JE. Courses in statistical computing and computational statistics. Am Statist. 2000;58(1):2-5. DOI: 10.10.1198/0003130042908

19. Abuelo JG. Normotensive ischemic acute renal failure. N Engl J Med. 2007;357(8):797-805. DOI: 10.10.1056/NEJMra064398

20. Sedlacek M, Suriawinata AA, Schoolwerth A, Remillard BD. Ciprofloxacin crystal nephropathy: a 'new' cause of acute renal failure. Nephrol Dial Transplant. 2006;21(8):2339-2340. DOI: $10.10 .1093 / \mathrm{ndt} / \mathrm{gfl} 160$

21. Goli R, Mukku KK, Raju SB, Uppin MS. Acute Ciprofloxacin-induced crystal nephropathy with granulomatous interstitial nephritis. Indian $\mathbf{J}$ Nephrol. 2017;27(3):231-233. DOI: 10.10.4103/0971-4065.200522

22. Ahmed MA, Tayawi HM, Ibrahim MK. Protective effect of Silymarin against kidney injury induced by carbon tetrachloride in male rats. Iraqi J Vet Sci. 2019;33(1):127-130. DOI: $\underline{10.2019 .125529 .1051 / \text { ijvs.10,33899 }}$
23. Schetz M, Dasta J, Goldstein S, Golper T. Drug-induced acute kidney injury. Curr Opin Crit Care. 2005;11(6):555-565. DOI: 10.10.1097/01.ccx.0000184300.68383.95

24. Nasir O. Renal and extrarenal effects of gum arabic (Acacia senegal) what can be learned from animal experiments? Kidney Blood Press Res. 2013;37(4-5):269-279. DOI: 10.10.1159/000350152

25. Nasir O, Umbach AT, Rexhepaj R. Effects of gum arabic (Acacia senegal) on renal function in diabetic mice. Kidney Blood Press Res. 2012;35(5):365-372. DOI: $\underline{10.10 .1159 / 000336359}$

\section{الاور الوقائي للصمغ العربي ضد السمية النفرونية

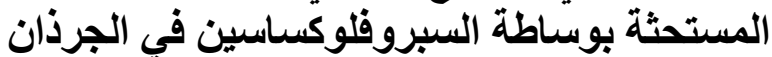

عبدالله ظاهر عبدالله و ميسر عبدالله احمد

العرم علوم الحباة، كلية التربية للعلوم الصرفة، جامعة تكريت، تكريت،

اكتسب الطب البديل إقبالا واسعا في الوقت الحاضر بسبب الأثار

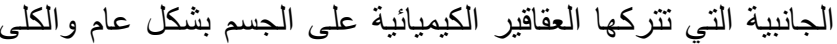

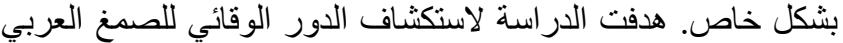
ضد السمية الكليونية الناجمة عن عقدة عقار السبروفلوكساسين. أربع

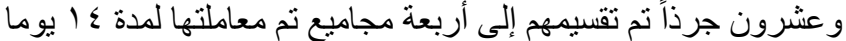

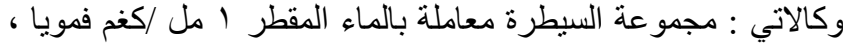

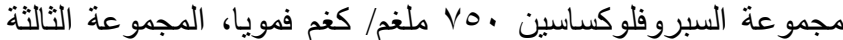

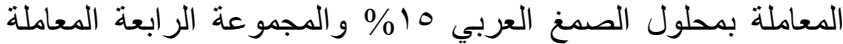

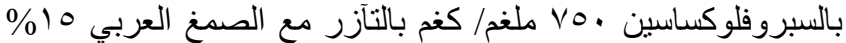

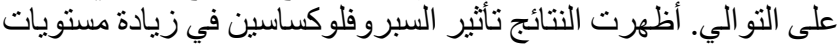

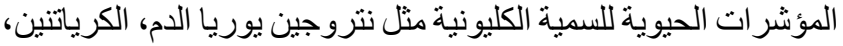

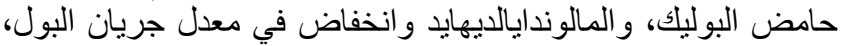

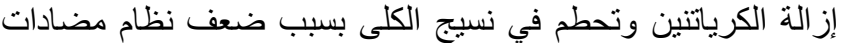

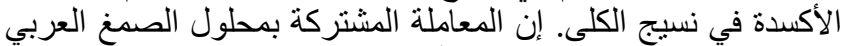

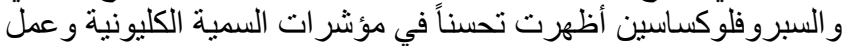

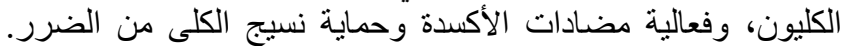

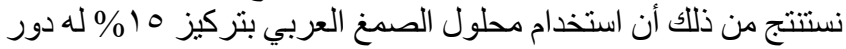

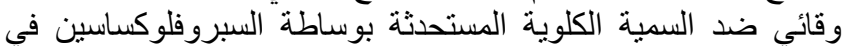

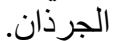

